\title{
TUTELA JURÍDICA DOS ARRANJOS PRODUTIVOS LOCAIS E EXPLORAÇÃO DA BIODIVERSIDADE EM GOIÁS: A PROTEÇÃO DA PROPRIEDADE INTELECTUAL COMO MECANISMO DE DESENVOLVIMENTO DAS COMUNIDADES TRADICIONAIS
}

\author{
LEGAL TREATMENT OF LOCAL PRODUCTIVE ARRANGEMENTS \\ AND THE EXPLOITATION OF BIODIVERSITY IN GOIÁS: THE LEGAL \\ PROTECTION OF INTELLECTUAL PROPERTY AS A MECHANISM \\ FOR DEVELOPMENT OF TRADITIONAL COMMUNITIES
}

Maria Cristina Vidotte Blanco Tarrega'

Ana Sofia Alencar Lambert ${ }^{2}$

\begin{abstract}
RESUMO: O presente estudo faz uma análise dos direitos de propriedade intelectual como instrumento para emancipaçâo das comunidades tradicionais no Estado de Goiás, notadamente daquelas organizadas em Arranjos Produtivos Locais - APLs, explorando-se o conceito e o tratamento jurídico de tais comunidades. Trata-se de pesquisa bibliográfica e documental que adota como fundamento a teoria de Amartya Sen sobre o conceito de desenvolvimento, entendido como concretizaçăo da qualidade de vida humana. Vale-se, ainda, do estudo do conceito de APLs e de sua importância para o reconhecimento das comunidades locais, bem como se procede, sinteticamente, à análise do que sâo os direitos de propriedade intelectual. Ademais, busca-se demonstrar a importância da tutela jurídica dos saberes tradicionais para o autorreconhecimento das coletividades nativas e para a preservaçăo da sociodiversidade brasileira.
\end{abstract}

PALAVRAS-CHAVE: Propriedade intelectual. Arranjos produtivos locais. Desenvolvimento sustentável. Comunidades tradicionais.

ABSTRACT: The present study analyzes intellectual property rights as an instrument for the emancipation of traditional communities within the State of Goiás, especially those organized around Local Productive Arrangements (LPAs). To do so, the concept of traditional communities and their treatment by the Law is explored. This study is a bibliographical and documentary research based on Amartya Sen's reflections about the concept of development, which should be understood as concretization of human quality of life. Also, this article explores the concept of LPAs and their importance for

1 Mestre e doutora em Direito pela PUC SP, Pós doutorado em Filosofia do Direito pela Universidade de Coimbra, Professora nos Programas de pós graduaçăo em Direito Agrário da UFG e em Direitos Coletivos e Cidadania da Universidade de Ribeirăo Preto. mcvidotte@gmail.com

2 Advogada, especialista em Direito, bacharel em Direito pela Universidade Federal de Goiás. anasofialambert@gmail.com 
the recognition of local communities, and analyzes, briefly, the concept of intellectual property rights. In addition, the present paper seeks to demonstrate the importance of traditional knowledge's legal protection for the self-recognition of native communities and also to the preservation of Brazilian sociodiversity.

KEYWORDS: Intellectual property. Local productive arrangements. Sustainable development. Traditional communities.

\section{INTRODUÇÃO}

A Conferência das Naçôes Unidas para o Meio Ambiente e o Desenvolvimento em 1992 - ECO 92, ratificada no Brasil em 1994, introduziu no ordenamento jurídico brasileiro o conceito de biodiversidade e de participaçăo das coletividades tradicionais na percepçăo dos benefícios das biotecnologias por elas produzidas, como forma de reconhecimento das identidades de tais comunidades.

O alto valor econômico de alguns saberes, que estăo por trás de grande parte da biotecnologia utilizada no país, acaba por despertar o interesse do capital, havendo a necessidade de resguardá-los. Por um lado, o auto-reconhecimento das populaçóes locais está intimamente ligado à proteçâo do conhecimento, técnicas produtivas e hábitos culturais dos povos nativos sobre o meio ambiente. Por outro, o valor econômico possibilita o crescimento patrimonial de referidas comunidades, oferecendo recursos que permitem melhor qualidade de vida.

Com o objetivo de atender às necessidades de proteçáo do conhecimento técnico científico das grandes empresas estrangeiras, implementou-se uma política internacional de patentes, destacando-se as TRIPS - Trade Related Intellectual Property Rights - formuladas pela Organizaçăo Mundial de Comércio - OMC em 1994. Tal acordo determinava maior rigor aos países quanto à proteçăo da propriedade intelectual relativa a pesquisas e conhecimentos técnico-científicos, beneficiando, assim, as empresas estrangeiras possuidoras de tecnologia em detrimento das coletividades detentoras dos conhecimentos tradicionais.

Embora o acordo em epígrafe gere verdadeiro retrocesso na emancipaçăo das coletividades nativas, a legislaçăo brasileira, com o intuito de regulamentar os saberes tradicionais, expediu a Medida Provisória 2.186-16/2001, posteriormente revogada pela Lei 13123 de 2015 e o Decreto n. 8772 de 2016. Baseada nas premissas disciplinadas pela Convençăo da Diversidade Biológica, estabelecida durante o ECO 92, previu a necessidade de aprovaçăo e participaçăo dos detentores do recurso genético a ser patenteado, assim como a repartiçâo justa e equitativa de seus benefícios.

A referida lei e seu decreto regulamentar que hoje disciplinam o acesso e uso do patrimônio genético da biodiversidade e dos conhecimentos tradicionais associados, assim como a repartiçăo dos benefícios dele decorrentes significou grande retrocesso para os interesses das comunidades tradicionais, embora preserve com muitas restriçóes a repartiçấo de benefícios. Em total desacordo com a ordem jurídica internacional contraria em diversos aspectos a Convençấo de Diversidade Biológica, o Protocolo de Nagoya e a Convençấo 169 da OIT, notadamente aqueles referentes aos direitos de consulta prévia, consentimento prévio livre e informado e repartiçăo de benefícios. 
As comunidades detentoras dos conhecimentos e técnicas tradicionais encontram-se muitas vezes agrupadas em centros de produçăo solidária e de cooperaçăo. Os Arranjos Produtivos Locais ou APLs, como săo chamados, consistem em aglomeraçôes territoriais de agentes econômicos, políticos e sociais, direcionados à realizaçăo de atividades específicas ligadas a determinado setor da economia. Trata-se de uma política pública de organizaçâo econômica para fomentar a sustentabilidade das comunidades tradicionais.

Importante questâo a ser debatida no âmbito dos APLs está na aplicaçâo dos direitos de propriedade intelectual aos produtos ali produzidos, destacando-se as indicaçôes de origem do produto comercializado. $O$ direito, aqui entendido como instrumento para o fortalecimento das comunidades tradicionais e de seus conhecimentos sobre a disposiçăo dos recursos naturais, deve ser compreendido em sua faceta mais democrática e inclusiva para promover a defesa das economias de pequena escala, arranjadas, plurais e autosustentáveis, visando a garantir a preservaçăo das diversidades culturais locais e dos recursos naturais.

Nesse sentido, tem-se por objetivos estudar os direitos de propriedade intelectual como forma de desenvolvimento das comunidades tradicionais e a possibilidade de organizaçâo em APLs no Estado de Goiás, identificando os instrumentos legais como meio de preservaçáo dos conhecimentos tradicionais e recursos naturais. Reflete-se sobre os resultados do uso de referidos direitos no fortalecimento das identidades culturais e na agregaçáo de valores aos produtos e aos serviços oferecidos, promovendo os diversos setores produtivos a partir de valores da cultura local.

Parte-se de matriz teórica proposta por Amartya Sen, sem prejuízo de outros autores, quanto à perspectiva de desenvolvimento humano, que năo se restringe ao mero crescimento econômico. Dessa forma, o avanço oportunizado pelo reconhecimento de direitos de propriedade intelectual às comunidades locais, que se aglomeram em centros produtivos tais quais os APLs, necessita ser compreendido em seu viés emancipatório. Deve-se utilizar o próprio sistema jurídico - que vem sendo aplicado como meio para a manutençăo das situaçôes hegemônicas no País e no mundo - para a emancipaçăo das coletividades tradicionais.

Em Goiás, existem hoje 49 arranjos produtivos locais identificados, dentre eles APLs voltados para agricultura e desenvolvimento agrícola. Percebe-se, assim, a relevância de tais agrupamentos como possibilidade para a afirmaçăo cultural e econômica dessas coletividades tradicionais no cenário econômico goiano, onde a atividade agrícola apresenta significativo relevo.

A pesquisa vale-se do método dedutivo, partindo das premissas estabelecidas pela Constituiçáo Federal, das noçôes de desenvolvimento econômico como emancipaçâo e reafirmaçấo, de Amartya Sen e de outros como Stavenhagen e Little e dos estudos sobre as comunidades tradicionais, para ao final fazer uma inter-relaçâo entre APLs, propriedade industrial, emancipaçâo dos grupos tradicionais do Estado de Goiás e sustentabilidade. Ademais, espera-se provocar uma reflexăo acerca da prospecçấo de soluçôes jurídicas e de novos instrumentos jurídicos para o estímulo ao desenvolvimento e construçăo da identidade cultural. 


\section{1 - TUTELA JURÍDICA DAS COMUNIDADES TRADICIONAIS}

O reconhecimento das comunidades tradicionais, no direito brasileiro, é resultado de processo que teve início na seara internacional, a partir dos crescentes debates que acompanharam as pressôes sociais e luta dos grupos marginalizados. As discussôes sobre a visibilidade de tais agrupamentos năo é tema novo no direito internacional, sendo possível identificar diplomas normativos que remontam à década de 1940 e 1950.

Como exemplo, aponta-se a Declaraçăo Universal dos Direitos Humanos de 1948, que dispôs sobre os direitos culturais, concebendo-os como garantia do meio social no qual o cidadăo se encontra inserido. A partir de entăo, passou-se a exigir dos Estados signatários medidas positivas para a efetivaçâo plena dos direitos sociais. Ademais, o texto permitiu, ainda que de maneira rudimentar, a emergência de grupos sociais que năo se enquadravam diretamente ao modelo cultural europeu, antes privados de qualquer amparo legal.

Também se destaca a Convençăo Relativa à Proteçăo do Patrimônio Mundial, Cultural e Natural de 1972. Consoante expóe Shirashi Neto (2004, p. 185), tal evento constitui verdadeiro "marco jurídico", porquanto possibilitou a distinçăo entre o patrimônio cultural e natural, bem como realçou a relevância desses bens para o desenvolvimento social.

Pouco depois, a Convençáo n 169/89, da Organizaçâo Internacional do Trabalho - OIT, tratou sobre povos indígenas e tribais, contestando a concepçăo de temporalidade e incluindo a ideia de que a "vida dos 'povos indígenas e tribais' é permanente e perdurável" (SHIRAISHI NETO, 2004, p. 186). Tal Convençăo buscou reforçar, ainda, a necessidade dos conceitos de auto-identificaçăo e de territorialidade para a subsistência dessas comunidades.

Outro importante evento internacional acerca do reconhecimento das comunidades tradicionais foi A Conferência das Naçôes Unidas para o Meio Ambiente e o Desenvolvimento em 1992 - ECO 92, ratificada no Brasil em 1994, da qual se originou a Convençâo da Diversidade Biológica. Esta, além de introduzir o conceito de biodiversidade no Direito Brasileiro, após sua ratificaçăo, previu a necessidade de aprovaçáo e participaçâo dos detentores do recurso genético a ser patenteado e a justa e equitativa repartiçâo de seus benefícios, como forma de afirmaçấo das identidades de tais comunidades.

No Brasil, a visibilidade dos grupos tradicionais tem seu marco na década de 1980 , em especial a partir do processo de redemocratizaçăo do país após o regime ditatorial. Com a promulgaçăo da Constituiçăo Cidadă, em 1988, as comunidades tradicionais tiveram sua sociodiversidade reconhecida pelo Direito, quebrando séculos de indiferença jurídica. É possível identificar, já no preâmbulo da Lei Maior vigente, a natureza pluralista da sociedade brasileira, agora formalmente reconhecida e relacionada às diversas maneiras de criar, fazer e viver e a processos culturais múltiplos e dinâmicos. Ademais, seu texto explicita o reconhecimento e a valorizaçấo das identidades tradicionais, notadamente nos arts. 215 e 216.

A tutela jurídica das comunidades tradicionais năo se esgota na previsăo constitucional. Nessa toada, pontua-se a importância da Política Nacional de Desenvolvimento 
Sustentável dos Povos e Comunidades Tradicionais, instituída pelo Decreto $n^{0}$ 6.040/2007, importante instrumento para a proteçâo de tais agrupamentos. Em seu art. $3^{\circ}$, inciso I, o diploma define povos e comunidades tradicionais como grupos reconhecidos e que se auto-reconheçam como culturalmente diferenciados, com formas próprias de organizaçăo social, "que ocupam e usam territórios e recursos naturais como condiçăo para sua reproduçấo cultural, social, religiosa, ancestral e econômica, utilizando conhecimentos, inovaçōes e práticas gerados e transmitidos pela tradiçâo;

Ao lado Carta Cidadá, os tratados e convençóes internacionais ratificadas pelo Brasil introduzem o objetivo de valorizar, preservar, e manter o modo de vida das comunidades tradicionais, com destaque à Convençâo nº 169/89 da OIT, cujo teor foi ratificado pelo Brasil pelo Decreto $n^{0}$ 5.051/04. Dentre os dispositivos de maior relevo, destacam-se o art. $1^{\circ}$, que eleva a auto-identificaçăo dos povos indígenas ao status de preceito fundamental, bem como seu art. $2^{\circ}$, o qual atribui aos governos dos países signatários a responsabilidade pelo desenvolvimento das comunidades tradicionais.

Em Goiás ganham destaque as comunidades quilombolas como referencial de comunidade tradicional, tendo em vista o seu grande número e a importância das comunidades do Estado, dentre as maiores do país.

Quanto a esse grupo em específico, a Constituiçăo Federal de 1988 dispôs, no art. 68 do Ato das Disposiçóes Constitucionais Transitórias - ADCT, relevante instrumento jurídico com o intuito de possibilitar sua sobrevivência e manutençấo, ao ressaltar que "aos remanescentes das comunidades dos quilombos que estejam ocupando suas terras é reconhecida a propriedade definitiva, devendo o Estado emitir-lhes os títulos respectivos".

A concepçăo de agrupamentos tradicionais encontra-se intimamente ligada à de auto reconhecimento. Nesse sentido, aplicando-se as premissas do estado democrático de direito, que adota como alicerce a dignidade da pessoa humana entre seus objetivos primordiais (art. $1^{\circ}$, inciso III, da Constituiçáo Federal) e a promoçăo do bem de todos, sem preconceito de origem, raça, sexo, cor, idade e quaisquer outras formas de discriminaçăo (art. $5^{\circ}$, caput, da Constituiçăo Federal), mister a necessidade de se assegurar os elementos de território, de auto-atribuiçăo e autonomia, os quais devem ser respeitados como direitos fundamentais embasadores da sociedade brasileira.

A auto-identificaçăo implica a percepçăo, pelo grupo, da coletividade culturalmente diversa do qual é possuidor, tendo em vista a memória, tradiçăo, laços de afetividade, reciprocidade e solidariedade. O auto-reconhecimento năo deve estar dissociada da capacidade de organizaçâo política, das políticas de conservaçấo dos recursos naturais básicos, da forma de uso comum dos mesmos e dos conflitos decorrentes do uso da terra e de tais recursos naturais (SHIRAISHI NETO, 2004a, s/p).

Dessa forma, no processo de empoderamento e construçăo da identidade quilombola, frisa-se a importância da auto-atribuiçâo (ou auto-reconhecimento, auto-identificaçâo), conforme o entendimento Sarmento (2008), esse critério é muito relevante tendo em vista que considera a percepçăo dos próprios sujeitos identificados, escapando do risco de leituras etnocêntricas ou essencialistas dos observadores externos originários de culturas diversas, por vezes leituras preconceituosas. Para o autor , a ideia fundamental pode reduzir-se ao princípio da dignidade da humana que exige que na questăo da identidade se considerar a visăo que o próprio sujeito de direito tem de 
si, sob pena de se perpetrarem sérias arbitrariedades e violências, concretas ou simbólicas (RODRIGUES, 2014).

Nesse ponto, importante salientar que o contexto social brasileiro, constituído por inegável diversidade étnica, é marcado pela existência de grupos possuidores de identidades específicas. Para a efetiva proteçăo a tais comunidades cabe, pois, assegurar o controle próprio das instituiçôes, do modus vivendi, hábitos, forma de subsistência, religiōes, dentre outros fatores, dever este atribuído ao Estado na forma de políticas públicas.

A territorialidade também exerce relevante papel na identidade das comunidades. Shiraishi Neto (2004a) considera território um "espaço para se construir a vida, as relaçōes e usos que se faz da natureza" (SHIRAISHI NETO, 2004a, s.p). Assim, fundamental a introduçấo do conceito de territorialidade, aqui compreendido como conjunto de relaçôes políticas, econômicas e culturais, entre os indivíduos ou o grupo social e seu meio de referência, denotando sentimento de pertencimento (ALBAGLI, 2003).

Verifica-se, pois, que território e identidade encontram-se fortemente interligados, porquanto a consolidaçăo do primeiro possibilita o surgimento de uma identidade própria do grupo que o ocupa (RODRIGUES, 2014, p. 31).

A autonomia de tais comunidades, por pressupor a preservaçâo do modus vivendi dos grupos tradicionais, relaciona-se também com fortalecimento de sua independência por meio da produçăo e comercializaçăo do que produzem. Sobre o tema, partindo da análise das comunidades quilombolas, Rodrigues (2014) reflete que nas comunidades tradicionais o processo de transformaçâo econômica dos bens é também um processo de transformaçăo cultural. Segundo o autor, o modo de produçăo das comunidades quilombolas é diferenciado pois transformam a natureza e transformam a si mesmas por meio de processos culturais permanentes, sustentados por laços de solidariedade, de afetividade e de envolvimento, tendo em vista a existência de interesses e objetivos comuns. O resultado é que a produçâo tem por finalidade básica e exclusiva a acumulaçâo, mas volta-se às necessidades humanas. "E essas necessidades estâo relacionadas a contextos específicos: às dos sujeitos envolvidos nesses grupos, que possuem hábitos e práticas culturalmente diversas do padrāo instituído" (RODRIGUES, 2014, p. 60).

O modelo produtivo dos grupos tradicionais distingue-se, pois, do modo de desenvolvimento capitalista de produçâo, o qual relegou às práticas agrícolas a satisfaçâo dos interesses do capital, acarretando no afastamento do objetivo primordial de satisfaçâo das necessidades humanas e transformando-se em negócio internacional altamente lucrativo.

Esse modo de viver e produzir tem alijado tais comunidades do sistema hegemônico e por essa razâo elas sofreram com indiferença e invisibilidade social durante muitos séculos, chegando inclusive a ser combatidas em razăo da falta de utilidade para a economia agrária predatória. Economicamente, constituem verdadeira afronta ao sistema vigente, por nâo primarem pela competiçăo e acumulaçăo de capital. Ao contrário, buscam a preservaçăo dos meios naturais e da biodiversidade, por configurarem seu próprio meio de vida. 


\section{2 - ARRANJOS PRODUTIVOS LOCAIS}

Năo há na legislaçăo brasileira definiçăo expressa do que seja um Arranjo Produtivo Local - APL. Năo obstante, a inexistência de lei específica que trate sobre o tema năo inviabiliza a efetivaçáo dos aglomerados produtivos na prática, sendo o tema tratado pela doutrina com especial relevo nos últimos anos.

A participaçâo de órgâos estatais, nesse sentido, mostra-se essencial para a concretizaçâo dos APLs. Como política pública de desenvolvimento regional, sâo promovidos, no Estado de Goiás, pela Secretaria de Ciência e Tecnologia - SECTEC.

No âmbito estadual, o Decreto Estadual n 5.990/2004 instituiu a rede goiana de apoio aos APLs, embora năo disponha sobre a organizaçăo, funcionamento, financiamento e produçâo dos mesmos. Traz breve definiçăo dos aglomerados, em seu art. $1^{\circ}$, parágrafo único, ao estabelecer que para os seus fins os Arranjos Produtivos Locais sâo "aglomerados de agentes econômicos, políticos e sociais, localizados em um mesmo espaço territorial, que apresentem, real ou potencialmente, vínculos consistentes de articulaçăo, interaçấo, cooperaçăo e aprendizagem para a inovaçăo tecnológica."

Destaca-se também o conceito trazido pela Rede de Pesquisa em Sistemas Produtivos e Inovativos Locais - Redesist, que repete em parte o conceito da lei explicando-o. Segundo a Rede "tratam-se de aglomeraçôes territoriais de agentes econômicos, políticos e sociais - com foco em um conjunto específico de atividades econômicas, podem ser agrárias ou nâo, que apresentam vínculos mesmo que incipientes." Informa a Rede que em regra eles envolvem a articulaçâo com empresas e que podem se dedicar à produçấo de bens e serviços finais, a fornecer insumos e equipamentos, prestar consultorias e serviços, entre outros e tem formas variadas de representaçấo e associaçâo. "Incluem também diversas outras organizaçōes públicas e privadas voltadas para: formaçăo e capacitaçăo de recursos humanos, como escolas técnicas e universidades; pesquisa, desenvolvimento e engenharia; política, promoçâo e financiamento" (2015).

Os APLs năo incluem apenas micro e pequenos empresários, como também envolvem a participaçăo de diversas outras instituiçōes, tanto públicas quanto privadas, relacionadas ao treinamento e formaçâo de capital humano, pesquisa, financiamento, dentre outras atividades. No Plano de Desenvolvimento do APL da Cerâmica Vermelha do Norte Goiano, é possível notar o alto número de entidades engajadas no fomento de aglomerados produtivos. Segundo informa o Plano, somente na esfera estadual estăo envolvidas neste APL: Rede Goiana de Apoio aos Arranjos Produtivos Locais/RG/APL, Secretaria de Ciência e Tecnologia/SECTEC, Rede Goiana de Meteorologia, Secretaria de Agricultura, Pecuária e Abastecimento/SEAGRO, Secretaria de Cidadania, Secretaria de Comércio Exterior, Secretaria da Educaçăo/SEE, Secretaria de InfraEstrutura - SEINFRA, Secretaria do Planejamento e Desenvolvimento/SEPLAN, Secretaria de Indústria e Comércio/SIC, Superintendência de Geologia e Mineraçâo/ SGM/FUNMINERAL, Secretaria do Secretaria do Meio Ambiente e Recursos Hídricos - SEMARH, Agência de Fomento de Goiás S/A, Agência Goiana de Desenvolvimento Regional - AGDR, Agência Goiana de Desenvolvimento Rural e Fundiário/Agência Rural, Agência Goiana de Desenvolvimento industrial - AGDI, Agência Goiana de Meio Ambiente - AGMA, Fundaçăo de Amparo à Pesquisa do Estado de Goiás - FAPEG, Universidade Estadual de Goiás - UEG, Fundaçâo Universidade Estadual de Goiás FUEG, Companhia Energética de Goiás - CELG, Federaçâo da Indústria do Estado de 
Goiás - FIEG, Federaçăo da Agricultura de Goiás - FAEG, Serviço de Apoio às Micro e Pequenas Empresa - SEBRAE-GO, Serviço Social do Comércio - SESC, Serviço Nacional de Aprendizagem Indústria - SENAI, Serviço Social da Indústria - SESI, Associaçāo Comercial de Goiás - ACIA-GO, Programa de Orientaçăo e Proteçâo ao Consumidor PROCON (Estado de Goiás, 2007).

Os aglomerados produtivos, por gerarem consciência coletiva através do exercício da solidariedade, permitem a autonomia dos membros das comunidades que os compóem. Mostram-se como verdadeiras formas de produçăo emancipatórias, por meio da inserçâo de comunidades antes excluídas do mercado de produçâo dentro do próprio sistema, transformando-os em "sujeitos que enfrentam as relaçōes sócio-culturais dominantes e as estruturas político-econômicas mantidas desde a invasăo portuguesa" (RODRIGUES, 2014, p. 59).

Trata-se forma de estímulo ao desenvolvimento da regiăo e inclusăo dos grupos tradicionais no mercado consumidor, pressupondo a participaçăo de toda a comunidade no processo produtivo, e pelo qual os sujeitos marginalizados convertem-se nos atores dessa nova perspectiva de desenvolvimento (SANTOS, 2005). Além disso, configuram importante instrumento para a concretizaçăo de direitos fundamentais, mediante exercício de uma economia baseada na cooperaçăo.

Ressalta-se que a identidade territorial, nesse aspecto, gera forte influência na eficiência das atividades econômicas, em razăo dos laços de proximidade desenvolvidos, valorizando-se as tradiçóes, os conhecimentos e vínculos de confiança, bem como novas estratégias de competiçăo.

Consoante Santos (2005), tais formas alternativas de atividades econômicas "náo representam novos modos de produçấo que substituam o modo capitalista. Contudo, isso năo lhes retira relevância nem potencial emancipador" (2005, p. 30-31). Ademais, assevera que "o pensamento associativista e a prática cooperativa desenvolveram-se como alternativas tanto ao individualismo liberal quanto ao socialismo centralizado" (SANTOS, 2005, p.33).

Em razăo de se aproximarem de um modelo de produçăo familiar, os APLs geralmente se organizam em torno de atividades econômicas de comunidades rurais, mas nada impede que se formem por aglomeraçăo de pequenas e micro empresas de alta tecnologia, como ocorre no APL de Tecnologia da Informaçăo, que abrange os municípios de Goiânia/GO e Aparecida de Goiânia/GO4.

A importância da constituiçấo dos aglomerados produtivos fica consignada no Plano de Desenvolvimento do APL de Açafrăo de Mara Rosa e Regiấo, cujos objetivos denotam a utilidade pública desses Arranjos:

Com ênfase no desenvolvimento local, priorizando o fortalecimento da agricultura familiar, buscando gerar emprego e renda nos municípios, o Governo de Goiás e demais instituiçôes têm priorizado o apoio a esta importante cadeia produtiva, que se configura como um novo negócio no mercado brasileiro (crescente demanda por condimentos, corantes naturais e possível utilizaçăo na indústria química). Através de políticas públicas, visando à conscientizaçâo e o aperfeiçoamento do processo produtivo e objetivando o fortalecimento deste APL, o grupo de trabalho vem propondo açóes conjuntas, objetivando compreender a situaçăo, solidificar parcerias e propor soluçôes para os pontos críticos, construindo assim um APL forte economicamente, justo socialmente e sustentável ambientalmente (OBAPL, 2017). 
Os dados fornecidos pelo Observatório Brasileiro de APL - OBAPL permitem concluir que existem hoje, no Estado de Goiás, oitenta e dois APLs constituídos em torno de variadas atividades. A atuaçấo integrada dos diversos atores envolvidos no processo de emancipaçấo econômica e social das comunidades tradicionais é o que possibilita a subsistência de tais aglomerados e, ademais, fomenta o surgimento de novos núcleos produtivos.

\section{3 - 0 DESENVOLVIMENTO DAS COMUNIDADES TRADICIONAIS PARA ALÉM DO PROGRESSO MERAMENTE ECONÔMICO}

Como se sabe, o modelo de desenvolvimento adotado pelo sistema capitalista baseia-se na exploraçáo dos meios naturais e do capital humano, como forma de potencializar os lucros e auferir maiores vantagens, acarretando o crescimento econômico de uma determinada regiăo. Contudo, o desenvolvimento econômico puro, medido por índices tais quais o PIB e a renda per capta, năo consegue exprimir o nível de qualidade de vida de uma populaçăo.

Para o presente estudo, a concepçăo de desenvolvimento é trabalhada sobre a teoria esposada por Sen (2001), que desenvolve uma crítica ao progresso sob uma perspectiva utilitarista. Para o autor, a teoria desenvolvimentista deve possibilitar o aumento da autonomia das comunidades humanas e a construçấo de um Estado no qual seus cidadăos tenham liberdade para serem e agirem como lhes aprouver.

A teoria da Abordagem das Capacitaçôes, como ficou conhecida, pressupóe que o desenvolvimento só poderá ocorrer à medida em que as pessoas sejam plenamente livres para tomar decisôes sobre a própria vida, de forma a concretizarem a dignidade humana por aplicaçăo dessa liberdade de escolha (SEN, 2001, p. 17). Por esse motivo, o progresso deve ultrapassar as barreiras da utilidade, inerentes ao desenvolvimento puramente econômico. Os índices que expressam o capital de um país só poderâo indicar qualidade de vida se acompanharem melhor distribuiçấo dessa riqueza e consequente conversăo em recursos para os cidadâos, a partir da análise da destinaçâo dos mesmos. Partindo desse pressuposto, Sen (2001) propóe o desenvolvimento para além do aumento de renda e da produçăo econômica, pautando-se também na ampliaçấo de outras dimensōes, tais quais a educaçâo, cultura, participaçâo política e saúde (2001, p. 95).

A teoria desenvolvimentista do autor se opóe a concepçăo de que os recursos do capital, que constituem meios, sejam o próprio fim do desenvolvimento. Ao contrário, a riqueza econômica é o instrumento necessário para que a populaçăo alcance melhor qualidade de vida, mas nem sempre será convertida dessa maneira (SEN, 2001, p. 5758). Por conseguinte, o fim do desenvolvimento é o incremento na qualidade de vida da populaçấo de uma determinada localidade, de forma que possibilite a tomada de escolha livre de qualquer "amarra" econômica. As oportunidades oferecidas à populaçăo sấo essenciais, mas nâo se traduzem automaticamente como desenvolvimento humano, se assim năo forem convertidas pela comunidade.

Ademais, o autor ressalta que as políticas públicas voltadas à promoçáo do desenvolvimento nâo devem se vincular à utilidade que trarâo para a sociedade. Ao contrário, 
têm de considerar a maior qualidade de vida oferecida aos particulares, sob o ponto de vista moral, e năo utilitarista. Devem estar fundadas na liberdade individual de tomada de decisóes, e nâo em fatores econômicos que consideram somente os meios e recursos oferecidos. Portando, Sen (2001) relaciona desenvolvimento como liberdade de ser e agir do indivíduo.

A acumulaçăo de capital nas măos de poucos, que demonstra a altíssima concentraçăo de renda brasileira, acaba por excluir e marginalizar os agentes detentores de menores recursos econômicos na cadeia produtiva. Por esse motivo, políticas públicas que fomentam a produçáo local constituem relevante instrumento para a melhora de qualidade de vida das populaçóes, porquanto possibilita a inserçăo dos mesmos no próprio modelo de produçâo que os marginaliza.

A negaçăo de acesso ao mercado configura uma das privaçôes enfrentadas por pequenos produtores, em especial por aqueles que pertencem às comunidades tradicionais, tais quais as quilombolas. A liberdade de participar do intercâmbio econômico tem papel básico na vida social (SEN 2001, p.22).

Dessa forma, combater a desigualdade de renda no país deve passar pelo enfrentamento das barreiras de acesso às riquezas (ROCHA e BURSZYTN 2007), de forma a propiciar uma ambiência favorável aos pequenos empreendedores, para os quais os efeitos de aglomeraçấo e de proximidade constituem vantagem dentro do sistema atual de acumulaçâo de capital. Segundo Rocha E Burszytn (2007) o caso recorrente na academia foi a experiência da Terceira Itália. Este caso mostra que é possível promover o desenvolvimento endógeno, sem imposiçôes hegemônicas. Sáo possíveis processos de desenvolvimento com participaçâo democrática, "com base no incremento dos micro e pequenos negócios tradicionais e, desse modo, construir um ambiente favorável à elevaçăo dos níveis de especializaçăo produtiva e densidade empresarial, sem a imposiçăo, ou o planejamento, de políticas de cima para baixo." (ROCHA e BURSZYTN, 2007, p. 9).Advertem que a açăo năo pode ser exclusivamente individual. "O sucesso só é alcançado no momento em que os atores locais, em parceria, cooperam em prol de objetivos comuns" (ROCHA e BURSZYTN, 2007, p. 9).

A necessidade de açóes direcionadas à equidade social e à sustentabilidade de tais comunidades tradicionais é, portanto, latente. $O$ acesso ao mercado configura-se ,dessa forma, elemento essencial para a ampliaçáo das capacidades humanas, bem como para a reduçấo da desigualdade de oportunidades existente entre os cidadāos. A economia de mercado pode, assim, ser utilizada como base para o incremente de renda das comunidades locais e permite, ao mesmo tempo, a participaçáo das mesmas nas relaçóes de troca.

Pode-se falar em etnodesenvolvimento, com duas acepçōes, que reforçam sua importância, significando num sentido, o desenvolvimento econômico de um grupo étnico e em outro o desenvolvimento da "etnicidade" de um grupo social (STAVENHAGEN, 1985). As acepçóes năo sâo excludentes entre si. Fortalece-se a "etnicidade" e avança-se no plano econômico. Um eventual desenvolvimento econômico destrutivo da "etnicidade" de um grupo reproduz a hegemonia da modernizaçâo, destruidora da diversidade cultural (LITTLE, 2002, p.40).

A perspectiva de desenvolvimento das comunidades tradicionais, notadamente a quilombola, é objeto de reflexâo de Rodrigues (2014), para quem as políticas públicas devem vislumbrar duas perspectivas integradas, visando à transformaçăo dos padróes 
societários o que compreende os culturais e os econômicos. Segundo a autora, de reconhecimento e de redistribuiçăo. Afirma que os governos Lula e Dilma, que construíram a história democrática do país com a mais ampla participaçăo, lançaram programas, planos e açōes procurando atender esses grupos. Adverte, entretanto que tais açōes e programas sâo resultado de resistência e luta: "É evidente que essas conquistas sâo frutos de embates históricos, surgidos em contextos específicos de mobilizaçôes sociais e respostas governamentais, quando constituíram verdadeiras arenas sociais, onde os interesses dos grupos eram/săo disputados e defendidos" (RODRIGUES, 2014, p. 18).

Nesse sentido, o acesso aos meios do capital, mediante inserçăo das comunidades no âmbito econômico, mostra-se importante dimensáo do desenvolvimento humano. É através de trocas, produçăo e realizaçăo do trabalho que as liberdades subjetivas florescem, porquanto a insurgência de recursos econômicos săo, sim, necessários, tendo em vista sua natureza instrumental para se alcançar o desenvolvimento individual pleno.

Ademais, o desenvolvimento das pequenas comunidades tradicionais, organizadas em aglomerados industriais e mediante inserçáo emancipatória no mercado, possibilita a preservaçăo de seu modo de vida juntamente com a biodiversidade de seu território. Para tais agrupamentos, a interaçăo com a terra e com o meio ambiente afasta-se da concepçăo capitalista de esgotamento e exploraçăo predatória, o que possibilita a conservaçăo do território em que se encontram.

\section{4 - 0 DIREITO À PROPRIEDADE INTELECTUAL COMO INSTRUMENTO EMANCIPATÓRIO}

Os direitos de propriedade intelectual săo bastante discutidos na doutrina, tendo relevância significativa no desenvolvimento das atividades empresariais e de inovaçăo tecnológica. Segundo Varella (2009 p. 330) esses direitos "garantem a exclusividade a seus titulares sobre a exploraçâo comercial sobre um determinado produto ou processo." Adverte o autor que em regra sáo outorgadas por um período determinado de tempo, mas já se identificam novos modelos de direito intelectual, năo limitados no tempo. (2009 p. 330)

Configuram medida de grande relevo para o fomento do desenvolvimento econômico de um país, uma vez que visam a estimular a produçăo e inovaçăo dos produtos inseridos no mercado, mediante a proteçấo do interesse individual do criador.

As discussóes acerca da proteçấo à propriedade intelectual năo sâo novidade no Direito. Já na Convençâo da Uniâo de Paris, em 1883, considerado marco inicial das questôes relativas ao tema, é possível extrair o conceito de propriedade intelectual, como um " conjunto de direitos que compreende as patentes de invençáo, os modelos de utilidade, os desenhos ou modelos industriais, as marcas de fábrica ou de comércio, as marcas de serviço, o nome comercial e as indicaçôes de provenência ou denominaçóes de origem, bem como a repressăo da concorrência desleal"7.

Ainda na seara internacional, vislumbram-se outros tratados a versar sobre o tema ora em estudo, como o Acordo de Madri de 1891, o Acordo de Lisboa em 1958 e o Acordo TRIPS de 1984, todos com o objetivo principal de promoçâo ao desenvolvimento econômico. 
Questăo relevante para o estudo dos saberes tradicionais é a titularidade de tais conhecimentos: pertencem às comunidades locais que culturalmente os detém ou sáo livres para a exploraçăo por grandes empresas, que mediante utilizaçăo de pesquisa e tecnologia de ponta acabam por patenteá-los?

Os direitos intelectuais elencados pelos TRIPS tornaram-se verdadeiro obstáculo à defesa dos direitos coletivos das populaçôes tradicionais. Conforme sustentam Zanirato e Ribeiro (2007, p. 46), fazendo alusâo a Shiva (2001), tais acordos identificam os direitos de propriedade como meros direitos privados, nâo os estendendo às coletividades. Ademais, só reconhecem o direito intelectual quando as inovaçōes geram lucro, e năo quando satisfazem as necessidades sociais.

A incompatibilidade entre a Convençâo da Diversidade Biológica de 1972 e os TRIPS é latente. $O$ primeiro reconhece a necessidade de proteçăo à diversidade sociobiológica, possibilitando às comunidades tradicionais o direito de participaçáo nos lucros auferidos por eventual patente conferida a empresas sobre conhecimento tradicional. Já o segundo exige a observância dos Estados signatários que sejam reconhecidos os direitos intelectuais absolutos sobre qualquer tecnologia (ZANIRATO e RIBEIRO, 2007).

No Brasil, o Acordo TRIPS foi publicado pelo Decreto $n^{\circ}$ 1.355/94 e acolhido pelo ordenamento jurídico interno. $O$ país também reconheceu a relevância da necessidade de se resguardar a proteçăo aos conhecimentos tradicionais, por meio da Medida Provisória 2.186-16/2001, que tratou da proteçáo ao patrimônio genético, posteriormente revogada pela lei .

Do teor da Medida Provisória 2.186-16/2001 é possível extrair vários dispositivos que denotam a preocupaçăo em resguardar os conhecimentos dos povos tradicionais, notadamente por garantir aos agrupamentos "que criam, desenvolvem, detêm ou conservam conhecimento tradicional associado ao patrimônio genético" a indicaçáo de origem do conhecimento tradicional, "em todas as publicaçôes, utilizaçôes, exploraçôes e divulgaçóes", bem como obstar a exploraçăo por terceiros năo autorizados, que năo poderăo utilizar, realizar testes, pesquisas ou exploraçáo do conhecimento tradicional, divulgar, transmitir ou retransmitir dados ou informaçôes que integram ou constituem os saberes tradicionais e perceber deles benefícios pela exploraçăo econômica por terceiros, direta ou indiretamente (art. $9^{\circ}$, incisos I a III).

Contudo, a Lei 13123 de 2015 e o Decreto 8772 de 2016 que hoje regulamentam o acesso e uso do patrimônio genético da biodiversidade e dos conhecimentos tradicionais associados, assim como a repartiçâo dos benefícios dele decorrentes, trouxeram significativo retrocesso para os direitos das comunidades tradicionais ao aumentar inúmeras possibilidades de exploraçăo sem respeitar os direitos de consulta prévia, consentimento prévio livre e informado e repartiçăo de benefícios.

A regulaçăo específica da matéria relativa à propriedade industrial encontra-se na Lei n. 9.279/96, especialmente sobre direitos e obrigaçôes. Em 1988, o direito à propriedade intelectual alcançou estatuto de preceito fundamental, previsto no art. $5^{\circ}$, inciso XXIX, da Constituiçăo, ao assegurar "aos autores de inventos industriais privilégio temporário para sua utilizaçấo, bem como proteçâo às criaçóes industriais, à propriedade das marcas, aos nomes de empresas e a outros signos distintivos". 
Para os fins do presente trabalho, a propriedade intelectual deverá ser entendida em seu viés desenvolvimentista, como instrumento de emancipaçăo das comunidades tradicionais. Dos modelos de proteçăo à propriedade intelectual adotados pelo ordenamento jurídico pátrio, destacam-se as indicaçôes de origem, que se dividem em indicaçăo de procedência e denominaçăo de origem, e possibilitam a distinçăo do produto colocado no mercado como advindo de determinada regiăo (ou comunidade local).

Como exemplo, aponta-se a produçâo de Carne de Curraleiro Kalunga, comunidade quilombola de Goiás, que possui a denominaçấo de origem "Gado Curraleiro Kalunga" como meio de fomentar sua produçâo, conferindo titularidade das mercadorias às comunidades tradicionais e tornando-os verdadeiros sujeitos ativos da atividade econômica. Nesse sentido, Franco (2014) entende que propriedade intelectual e desenvolvimento săo consectários entre si. Os direitos de propriedade intelectual posto em prática nas atividades econômicas agrícolas "pode consolidar um modelo de desenvolvimento para as comunidades rurais, principalmente em relaçăo à agregaçăo de valor e credibilidade de seus produtos no mercado" (FRANCO, 2014, p. 39).

As indicaçôes de procedência e a denominaçâo de origem encontram-se previstas na Lei n. 9.279/96, que as regula em seus arts. 177 e 178. Voltam-se a três finalidades principais: reconhecimento da procedência da mercadoria, sua originalidade, tipicidade e qualidade; proteçấo do produtor, mediante proteçăo de seu modo de produzir; e a proteçáo a consumidor, por garantir-lhe que está comprando produto conhecido (VARELLA, 2005).

Ademais, a especificaçăo do produto o valoriza, por conferir-lhe individualidade e, ainda, acaba por impulsionar a competitividade necessária (porém nāo predatória) ao crescimento econômico das comunidades inseridas no mercado. Com efeito, observa-se atualmente grande demanda por produtos orgânicos como alternativa à produçâo agrícola baseada na monocultura, uso desenfreado de agrotóxicos e vegetais transgênicos.

O desenvolvimento da economia, por propiciar recursos às populaçóes afetadas pelos APLs, gera meios para alcançar o desenvolvimento humano pleno, no modelo proposto por SEN (2001). Nessa toada, a proteçăo ao direito intelectual encontra campo promissor nos aglomerados produtivos, tanto naqueles que se valem do modo de produçấo integrado, quanto naqueles que recorrem à tutela do direito tradicional (TARREGA, 2012, p. 118).

Ao resguardar os saberes e técnicas de criaçăo, a proteçâo aos direitos intelectuais também volta-se à salvaguarda da própria biodiversidade, uma vez que o modo de produçấo dos grupos tradicionais se opôe à exploraçăo dos meios naturais de forma a esgotá-los, como vem ocorrendo com o modelo de exploraçăo capitalista, em especial o agrário. Quanto à relevância do tema, já nos posicionamos no sentido de que a proteçáo da indicaçăo geográfica tem origem na necessidade de proteçấo dos sujeitos envolvidos na fabricaçăo de produtos que característicos de dada regiăo, em relaçăo de pertencimento. "A qualidade desses produtos e serviços, cultural e economicamente reconhecidos, é de fundamental importância, também para a regiầ."(TÁRREGA, 2010, p.14).

Finalmente, frisa-se que năo só as indicaçōes de origem podem ser utilizadas como estratégia de desenvolvimento das comunidades tradicionais. A proteçấo à propriedade intelectual, seja qual for a modalidade adotada (patente ou marcas, por exemplo), 
possibilita a proteçấo dos saberes e técnicas tradicionais e, aliado ao fator da territorialidade, fortalece a identidade dos grupos e possibilita seu fortalecimento econômico.

\section{CONSIDERAÇÕES FINAIS}

Como visto, os povos tradicionais brasileiros sofreram com a marginalizaçâo e indiferença durante séculos de domínio do modelo de produçâo ocidental trazido do continente europeu. Por apresentarem formas diferenciadas de organizaçâo social, modos de viver, produzir e se relacionar com o mundo, foram excluídos do sistema hegemônico de produçâo e acumulaçăo de capital, submetidos à exploraçăo econômica desenfreada e desigual por parte das grandes empresas.

A proteçăo jurídica dos grupos tradicionais é história recente no cenário brasileiro, remontando à década de 1980, especificamente após a promulgaçăo da Constituiçấo Federal. O reconhecimento das comunidades tradicionais como verdadeiros sujeitos de direito merecedores das garantias constitucionais estendidas aos demais cidadâos constituiu importante vitória dos movimentos sociais reivindicatórios, que lutavam pela afirmaçấo de suas identidades e pela diminuiçăo das desigualdades sociais.

Visando ao fortalecimento e à subsistência dos agrupamentos tradicionais, o governo buscou a adoçâo de políticas públicas de fomento à produçáo econômica, ainda que sem amparo legal específico para a concretizaçăo das mesmas. Como exemplo de grande relevo, apontam-se os APLs, aglomerados produtivos locais baseados na economia de cooperaçấo e solidariedade entre seus membros.

Importante frisar que as políticas públicas de fomento regional devem estar voltadas à concretizaçấo da qualidade de vida aos povos envolvidos no processo de produçáo. Os índices baseados em fatores puramente econômicos, tais quais o PIB e a renda per capta, necessitam ser evitados quando se busca expressar real o desenvolvimento de uma sociedade, uma vez que este precisa estar vinculado ao desenvolvimento humano pleno, consoante a teoria esposa por Sen.

O estudo das políticas públicas para promoçăo da prosperidade das comunidades tradicionais, tais quais o fomento aos APLs, deverá, pois, ir além do aspecto meramente econômico, partindo-se da análise de melhoria na qualidade de vida das populaçóes locais beneficiadas, de modo a se desvincular da perspectiva utilitarista referente ao impacto na economia nacional.

No entanto, para que se atinja o progresso pleno dos agrupamentos tradicionais, necessário que se verifique também o crescimento econômico, haja vista que este constitui verdadeiro instrumento para que os agrupamentos potencializem suas liberdades e qualidade de vida.

Nesse sentido, os direitos de propriedade intelectual, por impulsionarem a produçăo local, săo de suma relevância para o fomento econômico de uma regiáo. Por meio da concessăo de indicaçóes de origem, marcas ou patente sobre os produtos, possibilita-se identificá-los e distingui-los dos demais, incrementando o crescimento do mercado de tais comunidades.

A teoria desenvolvimentista preconizada por Sen (2001), utilizada como base teórica do presente trabalho, pressupóe que o desenvolvimento como liberdade seja 
pleno, podendo ser concretizado mediante uso dos instrumentos jurídicos fornecidos pelo Direito, tais quais a propriedade intelectual para salvaguarda de mercadoria produzidas no seio das comunidades locais.

Mesmo que se verifique a tendência de favorecimento de grandes empresas pelas regras elaboradas no plano internacional, tais quais os Acordos dos TRIPS, a propriedade intelectual deve ser aplicada à luz da Constituiçâo Federal de 1988 e do ordenamento jurídico como sistema normativo harmônico. Desse modo, a concessâo de direitos industriais deve pautar-se pela máxima proteçâo aos saberes tradicionais inerentes às comunidades locais, conforme previa a Medida Provisória 2.186-16/2001 que, ao contrário de favorecer os agentes econômicos de grande porte, voltava-se ao fortalecimento dos laços de identidade de tais grupos, permitindo seu crescimento social e sua sobrevivência.

Entretanto, a Lei 13123 de 2015 e o Decreto 8772 de 2016 que revogaram a referida Medida Provisória 2.186-16/2001 e que hoje regulamentam o acesso e uso do patrimônio genético da biodiversidade e dos conhecimentos tradicionais associados , assim como a repartiçăo dos benefícios dele decorrentes, já năo mais privilegia os interesses das comunidades tradicionais, embora preserve com muitas restriçôes a repartiçâo de benefícios. Essa lei, em total desacordo com a ordem jurídica internacional, notadamente contrária à Convençăo de Diversidade Biológica, o Protocolo de Nagoya e a Convençấo 169 da OIT, lesando os direitos dos povos tradicionais, sobretudo no que diz respeito aos direitos de consulta prévia, consentimento prévio livre e informado e repartiçăo de benefícios.

Como instrumento de desenvolvimento utilizado no interior dos APLs, os direitos de propriedade intelectual, além de impulsionar os arranjos já existentes, fomentam o surgimento de novos núcleos, haja vista que dâo forma, publicidade e concretude às identidades relativas às comunidades locais ali reunidas.

O direito permite, assim, que grupos historicamente oprimidos se insiram no próprio meio hegemônico que os marginaliza, valendo-se dos instrumentos opressores como forma de sua própria emancipaçâo. A organizaçâo em aglomerados políticos locais, que primam pela solidariedade e competitividade comedida e tornam os agentes tradicionais sujeitos ativos do mercado de capital, ao lado utilizaçăo da proteçăo aos direitos intelectuais, mostram-se relevantes mecanismos que permitem nâo só o progresso econômico, mas também (e especialmente) o desenvolvimento humano pleno. 


\section{REFERÊNCIAS}

ALBAGLI, Sarita. Informaçăo, territorializaçâo e inteligência local. In: ENCONTRO NACIONAL DE PESQUISA EM CIÊNCIA DA INFORMAÇÄO, 5, 2003, Belo Horizonte. Anais... Belo Horizonte: ECI/UFMG, 2003. Disponível em: <http://repositorio.ibict.br/ bitstream/123456789/327/1/SARITAEnancib2003.pdf>. Acesso em: 14 de junho de 2015.

AUN, M. P; CARVAlHO, A. M. A; KROEFF, R. L. Aprendizagem Coletiva Em Arranjos Produtivos Locais: Um Novo Ponto Para As Políticas Públicas De Informaçāo. Disponível em: $\quad$ http://www.rp-bahia.com.br/biblioteca/pdf/AdrianeMariaArantesDeCarvalho. pdf $>$. Acesso em 03 de abril de 2015.

BRASIL. Análise do Mapeamento e das Políticas para Arranjos Produtivos Locais no Sul, Sudeste e Centro--Oeste do Brasil. Disponível em: <http://www.bndes.gov.br/SiteBNDES/ bndes/bndes_pt/Galerias/Arquivos/empresa/pesquisa/Mapeamento_GO.pdf〉. Acesso em: 06 de maio de 2015.

BRASIL. Constituiçâo Federal da República de 1988. Disponível em: <http://www.planalto.gov.br/ccivil_03/constituicao/constituicaocompilado.htm> Acesso em 20 de janeiro de 2015 .

BRASIL. Decreto 1.355/95. Disponível em: <http://www.planalto.gov.br/ccivil_03/decreto/Antigos/D1355.htm>. Acesso em: 02 de abril de 2015.

BRASIL. Decreto 5.051/04. Disponível em: <http://www.planalto.gov.br/ccivil_03/_ ato2004-2006/2004/decreto/d5051.htm>. Acesso em: 02 de abril de 2015.

BRASIL. Decreto 6.040/2007. Disponível em: <http://www.planalto.gov.br/ccivil_03/_ ato2007-2010/2007/decreto/d6040.htm>. Acesso em: 02 de abril de 2015.

BRASIL. Lei n. 9.279/96. Disponível em: <http://www.planalto.gov.br/ccivil_03/leis/ 19279.htm>. Acesso em: 02 de abril de 2015.

BRASIL. Medida Provisória 2.186-16/2001. Disponível em: <http://www.planalto.gov. br/ccivil_03/mpv/2186-16.htm>. Acesso em: 02 de abril de 2015.

BRASIL. Estado de Goiás. Secretaria de ciência e tecnologia. Mapeamento dos arranjos produtivos locais em Goiás. Disponível em: <http://www.sigo.go.gov.br/post/ver/127829/ mapeamento>. Acesso em: 06 de maio de 2015.

ESTADO DE GOIÁS. Análise do Mapeamento e das Políticas para Arranjos Produtivos Locais no Sul, Sudeste e Centro-Oeste do Brasil. Disponível em: <http://www.sgc.goias. gov.br/upload/arquivos/2012-03/mapeamento-apls_go.pdf>. Acesso em: 07 de abril de 2015. 
ESTADO DE GOIÁS. Decreto Estadual n. 5.990/2004. Disponível em: <http://www.gabinetecivil.goias.gov.br/decretos/numerados/2004/decreto 5990.htm〉. Acesso em: 12 de junho de 2015.

ESTADO DE GOIÁS. Plano de Desenvolvimento do APL da Cerâmica Vermelha do Norte Goiano. Disponível em: 〈http://www.sgc.goias.gov.br/upload/arquivos/2012-09/apl-de-ceramica-vermelha-do-norte-goianol.pdf >. Acesso em: 14 de junho de 2015.

ESTADO DE GOIÁS. Plano de Desenvolvimento do APL de Tecnologia da Informaçâo. Disponível em 〈http://www.desenvolvimento.gov.br/arquivos/dwnl 1248268461.pdf>. Acesso em: 10 de junho de 2015.

ESTADO DE GOIÁS. Plano de Desenvolvimento do APL de Mara Rosa. Disponível em: 〈http://www.mdic.gov.br/arquivos/dwnl_1248268492.pdf〉. Acesso em: 14 de junho de 2015.

FRANCO, R. N. A Funçăo Das Marcas, Das Patentes E Das Indicaçóes Geográficas Na Organizaçâo Dos Arranjos Produtivos Locais. 2014. 90 f. Dissertaçăo (Mestrado). Universidade Federal de Goiás, 2014.

LITTLE, Paul E. Etnodesenvolvimento local: autonomia cultural na era neoliberalismo global. Campo Grande. Tellus, ano 2, n.3, out. 2002, pp.32 -52. ONU, Organizaçâo das Naçôes Unidas. Conferência das Naçôes Unidas sobre o Meio Ambiente Humano. Declaraçâo de Estocolmo. IDisponível em: . http://www.dhnet.org.br/direitos/sip/onu/ doc/estoc72.htm>. . Acesso em: 12 ago. 2014.

ROCHA, J. D; BURSZTYN, M. Território, Saberes Locais e Sustentabilidade: A Busca do Desenvolvimento via Arranjos Produtivos Locais. In: Revista Baiana de Tecnologia. Vol. 22, nº 1-3. Camaçari: 2007.

RODRIGUES, B. L. R. Direito Ao Território: A Política De Regularizaçāo Fundiária Para As Comunidades Remanescentes De Quilombos No Estado De Goiás. 2014. 88 f. Dissertaçáo (Mestrado). Universidade Federal de Goiás, 2014.

RODRIGUES, B. L. R. Primeiros olhares sobre as políticas públicas para as comunidades remanescentes de quilombos. In: I Conferência Nacional de Políticas Públicas contra a Pobreza e a Desigualdade, 2010, Natal. Anais. Natal: UFRN, 2010, 1-10. Disponível em : <http://www.cchla.ufrn.br/cnpp/pgs/anais/Arquivos\%20GTS\%20-\%20recebidos\%20 em\%20PDF/PRIMEIROS\%20OLHARES\%20SOBRE\%20AS\%20POL\%C3\%8DTICAS\%20 P\%C3\%9ABLICAS\%20PARA\%20COMUNIDADES\%20REMANESCENTES\%20DE\%20 QUILOMBOS.pdf>. Acesso em 03 de março de 2015.

SANTOS, Boaventura de Sousa. Produzir para viver: os caminhos da produçâo nâo capitalista/organizador. 2. ed. Rio de Janeiro: Civilizaçâo Brasileira, 2005. (Reinventar a emancipaçáo social: para novos manifestos). 
SARMENTO,D.TerritóriosQuilombolaseConstituiçâo:AADI3.239eaConstitucionalidade do Decreto 4.887/03. Parecer emitido nos autos a ADI 3239/04. 2008. Disponível em: <hhttp://6ccr.pgr.mpf.mp.br/sobras/adi3239/territorios-quilombolas-e-constituicao-a-adi-3-239-e-a-constitucionalidade-do-decreto-4-887-03>. Acesso em: 15 de maio de 2015.

SEN, Amartya. Desenvolvimento como liberdade. Traduçâo: Laura Teixeira Motta. Revisáo técnica: Ricardo Donisseli Mendes. Sāo Paulo: Companhia das Letras, 2001.

SHIRAISHI NETO, Joaquim. O direito das minorias: passagem do "invisível" real para o "visível" formal?. Curitiba: Programa de Pós-graduaçấo em Direito da Universidade Federal do Paraná (PPGD/ UFPR), 2004a (Tese de Doutorado).

SHIRAISHI NETO, J. Reflexâo do Direito das "Comunidades Tradicionais" a partir das Declaraçôes e Convençôes Internacionais. In: Hileia: Revista de Direito Ambiental da Amazonia. Ano 2, n 3. Manaus: Ediçóes Governo do Estado do Amazonas / Secretaria de Estado da Cultura / Universidade do Estado do Amazonas, 2004.

STAVENHAGEN, R. Etnodesenvolvimento: uma dimensâo ignorada no pensamento desenvolvimentista, Anuário Antropológico/84. Rio de Janeiro: Tempo Brasileiro, 1985 p.11-44.

TARREGA, Maria Cristina V. B. A propriedade intelectual como instrumento para a organizaçăo dos arranjos produtivos locais - APLs -e para o desenvolvimento cultural e econômico das coletividades e comunidades tradicionais. In: Projeto Bolsa Produtividade em Pesquisa - PQ 2010. Goiânia: Faculdade de Direito da UFG, 2010.

TARREGA, Maria Cristina Vidotte Blanco. Os direitos das coletividades e os arranjos produtivos locais como fator de sustentabilidade das comunidades agrícolas tradicionais. Direito, Educaçâo, Ética e Sustentabilidade: Diálogos entre os vários ramos do conhecimento no contexto da América Latina e do Caribe. Coordenado por Jean Jardim. Goiânia: Instituto "tueri", 2012.

UFRJ: RedeSist. Disponível em: 〈http://www.ie.ufrj.br/redesist/foco.html〉. Acesso em: 14 de junho de 2015.

VARELLA, Marcelo Dias. Propriedade intelectual e desenvolvimento. Marcelo Dias Varella (organizador e co-autor). Săo Paulo: Lex Editora, 2005.

ZANIRATO, S. H.; RIBEIRO, W. C. Conhecimento tradicional e propriedade intelectual nas organizaçôes multilaterais. In: Ambiente \& Sociedade. Vol. X, n ${ }^{\circ}$. Campinas: 2007. p. 39-55.

ZANIRATO, S. H.; RIBEIRO, W. C. Convençâo de Paris para a Proteçâo da Propriedade Industrial. Disponível em: 〈http://www.planalto.gov.br/ccivil 03/decreto/1990-1994/ anexo/and1263-94.pdf >. Acesso em: 30 de abril de2015. 
ZANIRATO, S. H.; RIBEIRO, W. C. Convençăo nº 169 da OIT de 1989. Disponível em: <http:// www.cpisp.org.br/htm/leis/instrum01.htm>. Acesso em: 14 de junho de 2015.

ZANIRATO, S. H.; RIBEIRO, W. C. Observatório Brasileiro de APLs- OBAPL. Disponível em: 〈http://portalapl.ibict.br/apls/index.html . Acesso em: 12 de junho de 2015. 